\title{
In Situ Treatment of Manufactured Gas Plant Contaminated Soils Demonstration Program
}

\author{
Topical Report \\ March 1, 1995 - March 31, 1996
}

\author{
By: \\ Lyle A. Johnson, Jr. \\ L. John Fahy
}

Work Performed Under Contract No.: DE-FC21-93MC30127

For

U.S. Department of Energy

Office of Fossil Energy

Federal Energy Technology Center

Morgantown Site

P.O. Box 880

Morgantown, West Virginia 26507-0880

DSTRABUTION OF THS DOCUAENT IS UAH MITEO
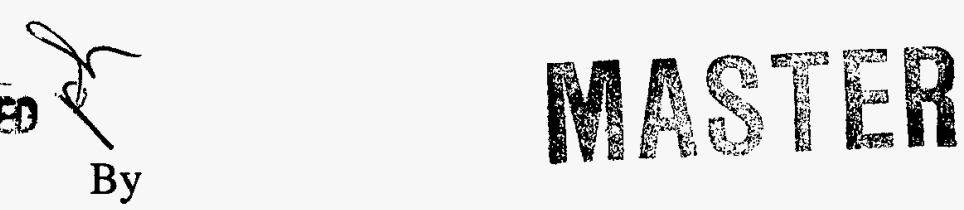

Western Research Instittue

365 North Ninth Street

Laramie, Wyoming 82070 


\section{Disclaimer}

This report was prepared as an account of work sponsored by an agency of the United States Government. Neither the United States Government nor any agency thereof, nor any of their employees, makes any warranty, express or implied, or assumes any legal liability or responsibility for the accuracy, completeness, or usefulness of any information, apparatus, product, or process disclosed, or represents that its use would not infringe privately owned rights. Reference herein to any specific commercial product, process, or service by trade name, trademark, manufacturer, or otherwise does not necessarily constitute or imply its endorsement, recommendation, or favoring by the United States Government or any agency thereof. The views and opinions of authors expressed herein do not necessarily state or reflect those of the United States Government or any agency thereof. 


\section{ACKNOWLEDGMENTS}

This report was prepared with the support of the U.S. Department of Energy (DOE), Morgantown Energy Technology Center, under Cooperative Agreement DE-FC93MC30127. However, any opinions, findings, conclusions, or recommendations expressed herein are those of the author and do not necessarily reflect the views of the DOE.

This Report was prepared as an account of work sponsored by an agency of the United States Government. Neither the United States Government nor any agency thereof, nor any of their employees makes any warranty, expressed or implied, or assumes any legal liability or responsibility for the accuracy, completeness, or usefulness of any information, apparatus, product, or process disclosed, or represents that its use would not infringe on privately owned rights. Reference herein to any specific commercial product, process, or service by trade name, trademark, manufacturer, or otherwise does not necessarily constitute or imply its endorsement, recommendation, or favoring by the United States Government or any agency thereof. The views and opinions of the author expressed herein do not necessarily state or reflect those of the United States Government or any agency thereof. 


\section{TABLE OF CONTENTS}

\section{Page}

LIST OF FIGURES $\ldots \ldots \ldots \ldots \ldots \ldots \ldots \ldots \ldots \ldots \ldots \ldots \ldots \ldots \ldots \ldots$

EXECUTIVE SUMMARY $\ldots \ldots \ldots \ldots \ldots \ldots \ldots \ldots \ldots \ldots \ldots \ldots \ldots \ldots$

INTRODUCTION $\ldots \ldots \ldots \ldots \ldots \ldots \ldots \ldots \ldots \ldots \ldots \ldots \ldots \ldots \ldots \ldots$

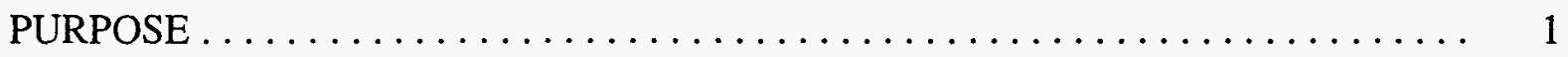

BACKGROUND $\ldots \ldots \ldots \ldots \ldots \ldots \ldots \ldots \ldots \ldots \ldots \ldots \ldots \ldots \ldots$

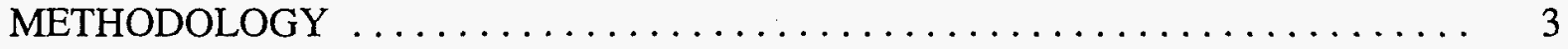

RESULTS AND DISCUSSION $\ldots \ldots \ldots \ldots \ldots \ldots \ldots \ldots \ldots \ldots \ldots \ldots \ldots \ldots \ldots$

Initial System Discussion $\ldots \ldots \ldots \ldots \ldots \ldots \ldots \ldots \ldots \ldots \ldots \ldots \ldots \ldots \ldots \ldots \ldots \ldots$

System Problems and Modifications $\ldots \ldots \ldots \ldots \ldots \ldots \ldots \ldots \ldots \ldots \ldots \ldots \ldots$

Results To Date $\ldots \ldots \ldots \ldots \ldots \ldots \ldots \ldots \ldots \ldots \ldots \ldots \ldots \ldots$

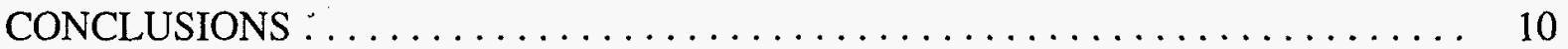

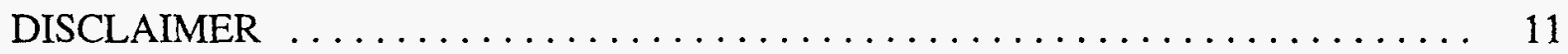

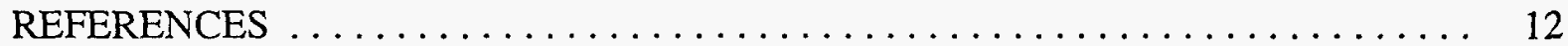




\section{LIST OF FIGURES}

Figure

Page

1. Theoretical Cumulative Organic Recovery Curve $\ldots \ldots \ldots \ldots \ldots \ldots .2$

2. Brodhead Creek Site Layout $\ldots \ldots \ldots \ldots \ldots \ldots \ldots \ldots \ldots \ldots \ldots \ldots$

3. System Flowrates for the Hot-Water Injection Period,

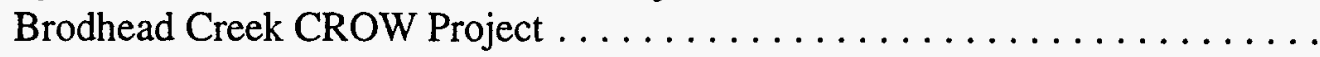

4. Actual Cumulative Organic Recovery Curve, Brodhead

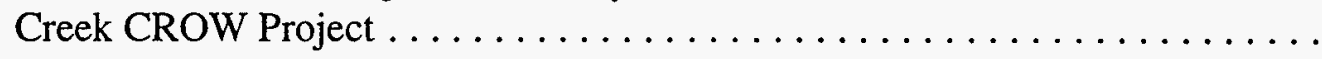




\section{EXECUTIVE SUMMARY}

The work performed in this study is Task 015, "In Situ Treatment of Manufactured Gas Plant Contaminated Soils Demonstration Program" of U.S. Department of Energy cooperative agreement DE-FC21-93MC30127.

The contained recovery of oily waste $\left(\mathrm{CROW}^{\mathrm{TM}}\right)$ process removes organic contaminants from the subsurface by adaptation of secondary and heavy oil recovery technology. The technology was successfully tested in the laboratory as part of a project for the U.S. Environmental Protection Agency (EPA) SITE Program's Emerging Technology Program. The EPA advanced the CROW process to the SITE Demonstration Program based on the laboratory performance. Additional development of the process has included a pilot test at an active wood treatment facility. The purpose of this project is to demonstrate and evaluate the effectiveness of the CROW process for remediation of a site contaminated primarily with a dense organic fluid. The site selected for this demonstration project was a former manufactured gas plant (MGP) site located in Stroudsburg, Pennsylvania.

Because the selected site is a Superfund site, the procedures required for this project are established by the EPA. The project design process required the development of a detailed work plan followed by a sequential site design of three steps: (1) a 30\% design for the field layout and operation; (2) a $95 \%$ design for the field layout and operation with all equipment, well construction, and operating procedures fully specified; and (3) a final project design based on the review comments from the $95 \%$ design submission.

The initial progress of the project was slowed by additional requirements such as recharacterization of the site as requested by the EPA, the time required for design and approval protocol, and completion delays due to both weather and manpower availability. To date all facility construction and the system shakedown has been completed. During shakedown of the system operational problems with control of the hot-water heater, with the integrity of the injection wells in the shallow, unconsolidated aquifer and with the injection wells and treatment system caused by production of dissolved iron from the aquifer resulted in further delays. With time, all of the operational problems have been corrected or changes in the operational procedures have been made to minimize the problems.

During the 230-day shakedown period, $5.4 \times 10^{6} \mathrm{gal}$ of ambient temperature water were injected and $7.3 \times 10^{6}$ gal of fluid were produced from the pattern area. The remaining $1.9 \times 10^{6} \mathrm{gal}$ were treated by the biological reactor system and disposed of. Since initiation of the hot-water injection, $6.9 \times 10^{6} \mathrm{gal}\left(15\right.$ pore volumes) of water at an average temperature of $150^{\circ} \mathrm{F}$ have been 
injected. The average injection temperature includes periods of downtime, since heat losses affect the process. During these 256 days of hot-water injection, $8.6 \times 10^{6} \mathrm{gal}$ (19 pore volumes) of fluid have been produced with $1.7 \times 10^{6}$ gals treated for disposal. 1500 gal of coal tars have been produced. 


\section{INTRODUCTION}

The contained recovery of oily waste $\left(\mathrm{CROW}^{\mathrm{TM}}\right)$ process removes organic contaminants from the subsurface by adaptation of technology used for secondary and heavy oil recovery. The CROW technology was successfully tested in the laboratory as part of a project for the U.S. Environmental Protection Agency (EPA) SITE Program's Emerging Technology Program (Johnson and Guffey 1990). The development consisted of several one- and three-dimensional physical simulations of the process. The preliminary testing showed that hot-water flushing could reduce the contaminant content by approximately $60 \mathrm{wt} \%$. Additional testing with totally biodegradable chemicals showed that the removal rate could be increased to approximately $90 \%$. Based on the laboratory performance of the process, the EPA advanced the process to the SITE Demonstration Program.

Further development of the process has included the completion of a pilot test at an active wood treatment facility. The pilot test provided additional information for the design of a field-scale remediation effort in addition to verifying several of the prepilot design specifications and predictions. Verified by the pilot test were the abilities to: (1) establish and maintain desired injection and extraction rates, (2) heat the test area to the desired temperature, (3) achieve non-aqueous phase liquid (NAPL) removal rates equivalent to laboratory rates, and (4) show that the produced fluid can be treated for reinjection or disposal (Fahy et al. 1992).

\section{PURPOSE}

The purpose of this project is to demonstrate and evaluate the effectiveness of the CROW process to remediate a site contaminated with a dense organic fluid. The effectiveness will be measured by attaining in the field treatment levels set by the EPA, which are comparable to prior laboratory results.

\section{BACKGROUND}

The site selected for this demonstration project was a former manufactured gas plant (MGP) site located in Stroudsburg, Pennsylvania. The site is the Brodhead Creek Superfund site owned by Pennsylvania Power and Light (PP\&L). For approximately 60 years prior to the mid 1940s, a manufactured gas plant utilizing coal gasification was operated at the site. From the mid 1940s until 1980 , the site was essentially abandoned. In 1980, repair of a flood control levee at the site identified coal tar contamination through seeping of the substance into construction cuts. In 1982, the site was 
placed on the National Priorities List. Remedial investigation and feasibility studies conducted in the late 1980s and early 1990s resulted in the selection of the CROW process as a remediation alternative in the 1991 interim record of decision.

The contamination at the site is in the uppermost geologic unit, a loosely consolidated to unconsolidated aquifer consisting of rounded boulders, cobbles, and gravel with varying amounts of sand. This unit overlies a fine-grained sand and silt that acts as an aquitard. The contaminated unit runs from the surface to a depth of approximately $35 \mathrm{ft}$ in the process area, with the contamination concentrated in a depression in the center of the area. The top of the water table ranges from 3 to 15 feet below ground surface in the process area and has an extremely high hydraulic conductivity equivalent to 100 to 150 Darcies.

The development of the operational parameters for the project were based on one- and threedimensional physical simulations of the process conducted for the EPA SITE Program's Emerging Technology Program (Johnson and Guffey 1990). The preliminary testing demonstrated that hot-water flushing could reduce the contaminant content by $60 \mathrm{wt} \%$. Additional testing showed that the CROW process did not hinder but helped in the biodegradation of the residual organics following processing (Johnson and Leuschner 1992). The EPA established as a treatability goal for the project the removal of contaminants to a level equivalent to that in the preliminary testing. The measure of attaining this goal would be an increase in the cumulative organic recovery of less than $0.5 \%$ per pore volume of injected water, Figure 1, and the raising of the temperature in the treatment area to the 150 to $160^{\circ} \mathrm{F}$ range.

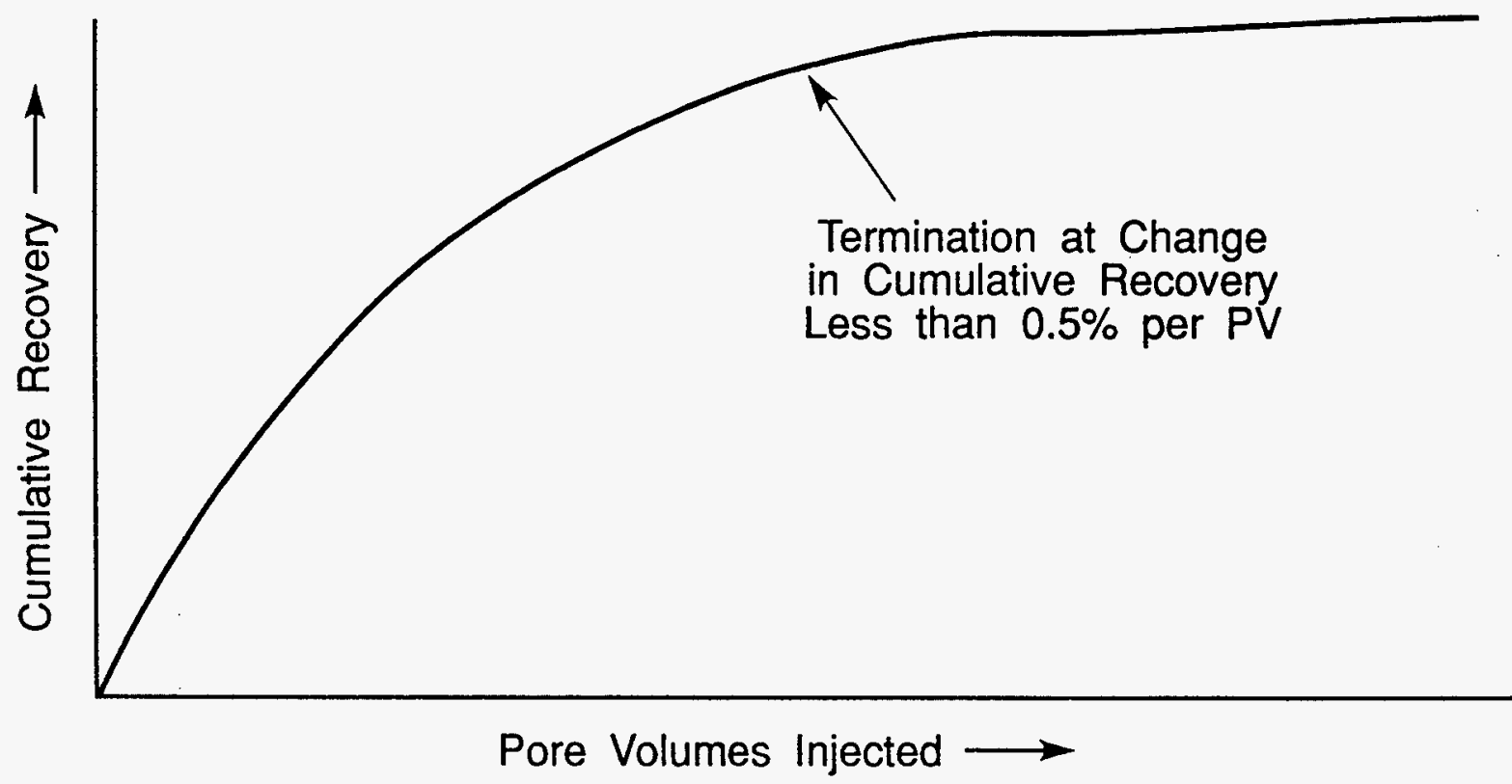

Figure 1. Theoretical Cumulative Organic Recovery Curve 
The funding for the project is provided by U.S. Department of Energy (DOE), Pennsylvania Power and Light, Gas Research Institute, and Electric Power Research Institute. WRI in conjunction with Remediation Technologies Inc. is responsible for the design, construction, and operation of the project. Other participants working at the site include Atlantic Environmental Services Inc. (site characterization); Michigan Biotechnical Institute, now EFX Systems Inc. (water treatment for disposal), and the U.S. EPA SITE Demonstration Program (process monitoring, analysis, and evaluation).

\section{METHODOLOGY}

The procedures followed for this project are those required by the EPA for remediation projects at hazardous waste sites. The CROW process could be used at this site because enhanced remediation techniques were identified and approved as potential methods in the Record of Decisions for the site. The first item required to be completed was to develop and submit for approval a detailed work plan. The work plan identified all required construction and environmental permits and showed that the project design would be completed in a sequence of three steps: (1) Prepare and submit for approval a 30\% design for the field layout and operation; (2) Prepare and submit a 95\% design for the field layout and operation, with all equipment, well construction, and operating routines fully specified; and (3) prepare a final project design based on the review comments from the $95 \%$ design submission.

Following approval of the project design, all required equipment installation and construct the field facilities would be done, followed by the actual operation of the field demonstration. Upon completion of the field demonstration, the field facility would be dismantled and the data analyzed. Report of the results would be made to the DOE, PP\&L, EPA, and other cosponsors.

\section{RESULTS AND DISCUSSION}

The work plan for the field demonstration was submitted to and approved by the EPA Region 3 office. Following approval, the three step system design and approval sequence was initiated and completed. The Pennsylvania Department of Environmental Resources (PADER) was also included

in the review of the design and operational requirements of the project. Also identified and obtained were all the environmental and construction permits required for the project. 


\section{Initial System Discussion}

The field facility consisted of a well pattern, a water injection system, a fluid extraction and separation system, a water treatment system, and a data acquisition and control system (DACS). The well pattern consisted of two interconnected, inverted five-spot patterns for a total of 2 extraction wells, 6 injection wells, and 8 monitor wells, Figure 2. Extraction system components consisted of the 2 extraction wells and the separation and storage tankage. The extraction wells were screened throughout the water table and contained two submersible pumps per well. In each well, one pump was placed at the bottom of the well and the other pump two to three feet below the top of the aquifer. The lower pump is the main extraction pump with the upper pump used to remove any light organics displaced to the well. The pumps are controlled by a series of level controllers and conductivity meters in the wells and the production tanks.

The production tankage consisted of four 20,000 -gal and one 10,000-gal tanks. All extracted fluids, a maximum of $120 \mathrm{gpm}$ of organics and water, first enter one or both of the first two 20,000 gal tanks through a spreader. The majority of the heavy organics separate in the first two tanks, with the remaining fluid flowing overhead to a third 20,000 gal skimmer tank with a floating skimmer unit. Additional heavy organics settle to the bottom of the skimmer tank and light organics rise to the top for removal by the skimmer unit. Water is removed from the skimmer tank at a point $6 \mathrm{ft}$ from the bottom and is pumped to a 20,000 -gal recycle water storage tank. The heavy organics from the bottom of the first three tanks and the light organics from the top of the skimmer tank are pumped to the 10,000 gal organic storage tank. Provisions were made in the production system for acid or sodium hydroxide injection into the production piping to regulate the fluid $\mathrm{pH}$. This regulating of the produced fluid $\mathrm{pH}$ was to assist in the separation of the organics and the regulation of calcium precipitation.

The water injection system consisted of the 6 injection wells and a hot-water heater. The 6 injection wells were completed by screening and gravel packing the bottom three-quarters of the water table and then sealing the annular area above the screen with $1 \mathrm{ft}$ of bentonite pellets and then cement to the surface. Injected water, up to $100 \mathrm{gpm}$, is pumped from the recycle-water tank through a hot-water heater and distributed by an injection manifold. The heater is a single pass, 2000 watt electrical heater with four heater-element bundles.

Water treated for disposal, up to $20 \mathrm{gpm}$, is pumped from the recycle-water tank to the granular activated carbon-fluidized bed reactor (GAC-FBR). Maximum capacity of the GAC-FBR is $190 \mathrm{gpm}$. The reactor uses a biological process in which the biological degrading organisms are grown on the granular activated carbon (Gruber 1996). The design, construction, and operational procedures for the GAC-FBR were provided by EFX Systems Inc. 


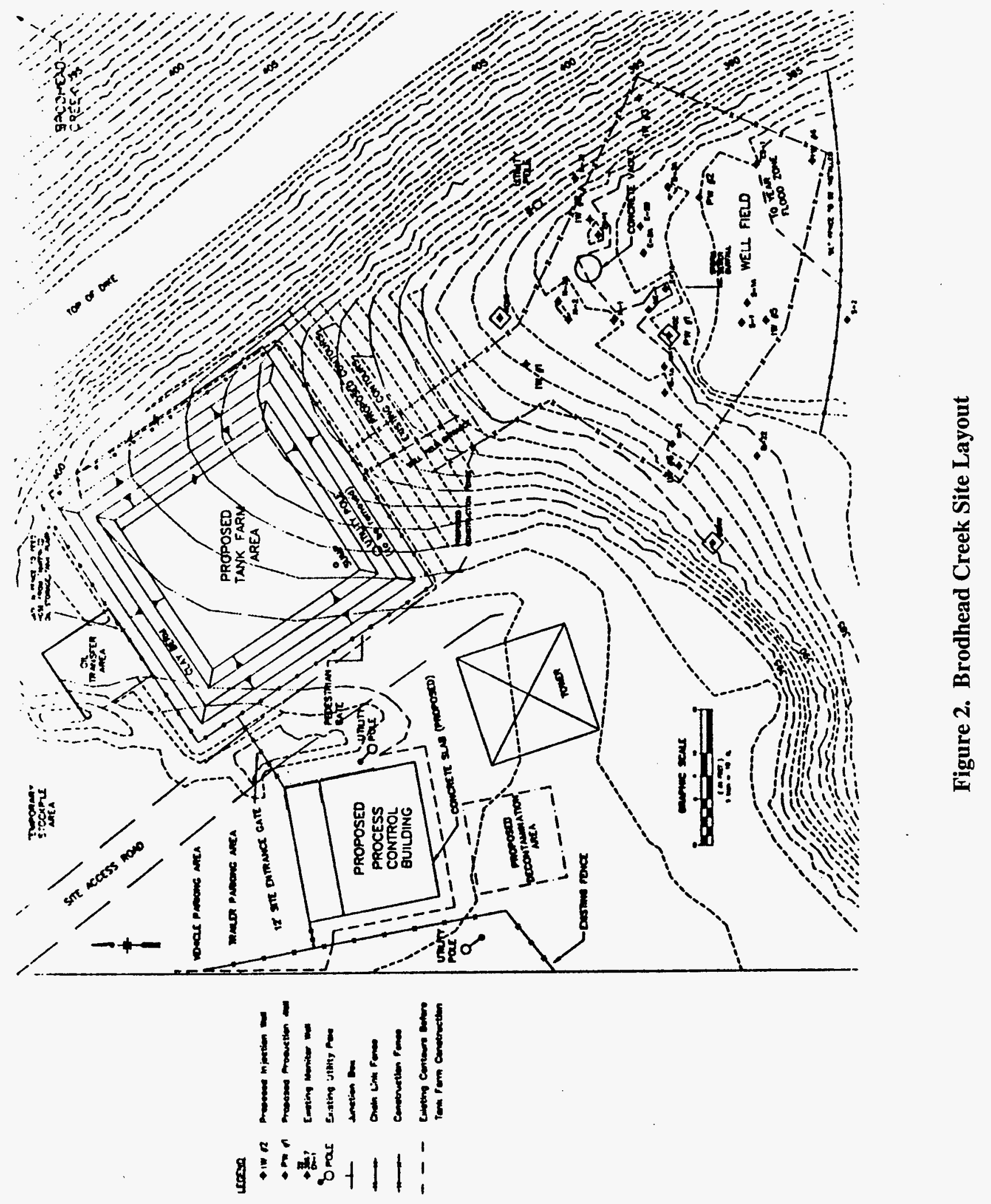


The data acquisition and control system is a PC-based system operating with LabTech Control software. The system gathers data from flowmeters on all extraction and injection lines; thermocouples in all wells; level sensors in the extraction wells and production tanks; and conductivity meters in selected tanks, lines, and in the extraction wells. All data is collected approximately every 10 seconds and stored every 5 minutes. System control and shutdown is based on the collected data in conjunction with the ladder logic developed for the system.

\section{System Problems and Modifications}

Shortly after initiating cold-water injection during system shakedown, a problem with establishing satisfactory injection rates was noted for wells IW3, IW4, and IW5. The problem with IW4 and IW5 was the lack of competent overburden to establish a good seal around the well, which prevented the use of injection pressures necessary for satisfactory injection rates. The surface in the area of these two wells was approximately $3 \mathrm{ft}$ above the water table and was the same boulder/cobble/gravel material as the aquifer. To correct the problem with these wells, both wells were redeveloped to remove any debris inside the screens, then a thermal packer was installed to restrict injection into the bottom $10 \mathrm{ft}$ of the well. The redevelopment effort consisted of surging large volumes of water within the casing and screen to free any residual drill cuttings or other material that would restrict flow through the screens. The surging was continued until the recovery rate of the well was satisfactory. This effort provided little, if any, improvement in the injection rates. Injection rates greater than 1 to $3 \mathrm{gpm}$ were never achieved for these wells.

The problem with the injection into IW 3 was caused by the positioning of the well up on the levee wall. It appears that the well was completed in the fringe area of the bentonite core in the levee. This bentonite-contaminated material would restrict communication with the other pattern wells. Redevelopment of this well to clean out any residual debris, of which there was approximately $10 \mathrm{ft}$, did not improve the well performance. For all practical purposes, this well was nonfunctional as a pattern well.

The other injection problem was the continual decrease in the injection rates for wells IW1, IW2, and IW6. Analysis of the reddish-white slime that was clogging the well screens and strainers and fouling the turbine flow meters in the injection system indicated a high iron content. The source of the iron was high concentrations of dissolved iron in the aquifer. These high iron concentrations were not previously noted. To remediate the problem, the water production and treatment system was modified to remove the iron, and the injection system and wells were cleaned. The modifications consisted of repiping the first two production tanks so that all production went first to tank 1 then from the top of tank 1 to the bottom of tank 2 . The chemical injection systems were then activated to reduce the $\mathrm{pH}$ of the produced fluid to 5 prior to tank 1 . The reduction in $\mathrm{pH}$ was done with $93 \%$ 
sulfuric acid to improve separation of the organics from the produced fluid in tank 1 . The water overflowed from tank 1 to tank 2 , where the $\mathrm{pH}$ was increased to the 7 to 8 range with $25 \%$ sodium hydroxide prior to adding $50 \%$ hydrogen peroxide and a flocculent to precipitate the dissolved iron. The $\mathrm{pH}$ of the produced water recycled to the injection wells was maintained at approximately 8.5 to prevent precipitation of calcium when the water as heated. To assist in the removal of any precipitate that passed the tank system, filters were installed before and after the hot-water heater.

The injection piping and well cleaning connected to the iron problem consisted of the flushing of all piping to remove the sediments and the redevelopment of the wells to remove any deposition. To assist in keeping the wellbores clean, a jettering system was installed in all of the injection wells. The jettering, system consisted of an air jet installed on a lance that penetrated to near the bottom of each injection well. Compressed air was then used to create a surging effect in the wellbore to clean the screen and to remove the displaced precipitates. During jettering acid and/or chlorine could be added to assist in the cleanup. The modification of the treatment system and the well redevelopment helped the injection problem but has not totally eliminated it. As with IW4 and IW5, the lack of a competent overburden has restricted injection in wells IW1, IW2, and IW6. These combined problems have limited the injection rates into these wells to about half of the desired rate of $17 \mathrm{gpm}$ per well.

Problems with establishing and maintaining the predicted injection rate have caused problems with the extraction wells and the hot-water heater. The hot-water heater was designed to heat 75 to $100 \mathrm{gpm}$ of water from 50 to $200^{\circ} \mathrm{F}$ using an on/off control system. Since the maximum injection rate has been approximately $30 \mathrm{gpm}$, the control of the heater was unsatisfactory. To combat this problem, three of the four heater bundles in the heater were disconnected, and the fourth bundle was connected to a proportional controller. The operation of the heater has been better since this change. If additional heat is needed, one of the remaining heater bundles will be put back on on/off control to provide preheat to the injected water.

The extraction well problem stems from the sizing of the two extraction pumps at $60 \mathrm{gpm}$ to supply 110 to $120 \mathrm{gpm}$ of total recovery. Since the maximum injection rate has been approximately one-third the planned rate, the extraction rate had to be reduced to one-third. This low extraction rate has caused undo wear on the pump motors and impellers as the result of heat buildup in the pump. Repair and replacement of the downhole pumps has become more frequent as the project has continued.

Other operational problems have occurred with the biological treatment unit, organic fouling of the level indicators, particulate fouling of turbine flowmeters, and the DACS. Tuning of the biological treatment unit took several months, and the carryover of some granular carbon and 
biological material from the fluid bed caused plugging of the pumps and carbon adsorption drums in the discharge system. To prevent the plugging, strainers and micron-sized filters were installed before and after the fluidized bed. Problems with the level indicators and flowmeters have resulted in an extraordinary amount of cleaning, repair, and replacement of the instruments.

Problems with the DACS were hangups of the control system at random times. Several attempts to reconfigure the system, remove unnecessary software, and routine rebooting of the system did not remedy the problem. The problem was corrected by installation of Windows 95.0 and new versions of LabTech Control and Carbon Copy. Since installation of these new software packages, problems with the control system have been rare.

Other modifications to the operational system have included moving well pumps and piping some of the monitor well for injection purposes. Extraction pump changes have included the removal of the upper pumps from the extraction wells and installation of the pumps into monitor wells RCC and RCNE. This change was made because no noticeable floating organics were found in the extraction wells and there appeared to be small pools of organic around RCC and RCNE. This pump change has eliminated the organics around the monitor wells. Also, piping of monitor wells for injection purposes has been done in the area around IW4 and IW5 to increase the hot-water flow in that area.

\section{Results To Date}

Construction of the field facilities began in mid 1994 and was completed in the fall of 1994. Shakedown of the system began in November 1994 and continued through June 1995. Problems associated with the operation of the system were addressed during this shakedown period. Beginning in July 1995, hot-water injection was established and has been nearly continuous since that time.

During the 230-day shakedown period, $5.4 \times 10^{6} \mathrm{gal}$ of ambient temperature water were injected, and $7.3 \times 10^{6} \mathrm{gal}$ of fluid were produced from the pattern area. The remaining $1.9 \times 10^{6} \mathrm{gal}$ were treated by the biological reactor system and disposed of. Since initiation of the hot-water injection, $6.9 \times 10^{6} \mathrm{gal}\left(15\right.$ pore volumes) of water at an average temperature of $150^{\circ} \mathrm{F}$ have been injected. The average injection temperature includes periods of downtime. During these 256 days of hot-water injection, $8.6 \times 10^{6} \mathrm{gal}$ (19 pore volumes) of fluid have been produced with $1.7 \times 10^{6}$ gal treated for disposal. The average injection and extraction rates for the hot-water injection period have been 18.6 and $23.8 \mathrm{gpm}$, respectively (Figure 3 ). Since beginning the operation of the system, 1500 gal of coal tar have been produced (Figure 4). The theoretical and actual cumulative organic recovery curves (Figures 1 and 4, respectively) have the same shape, indicating that for the present operational conditions, essentially all producible organics have been recovered. 


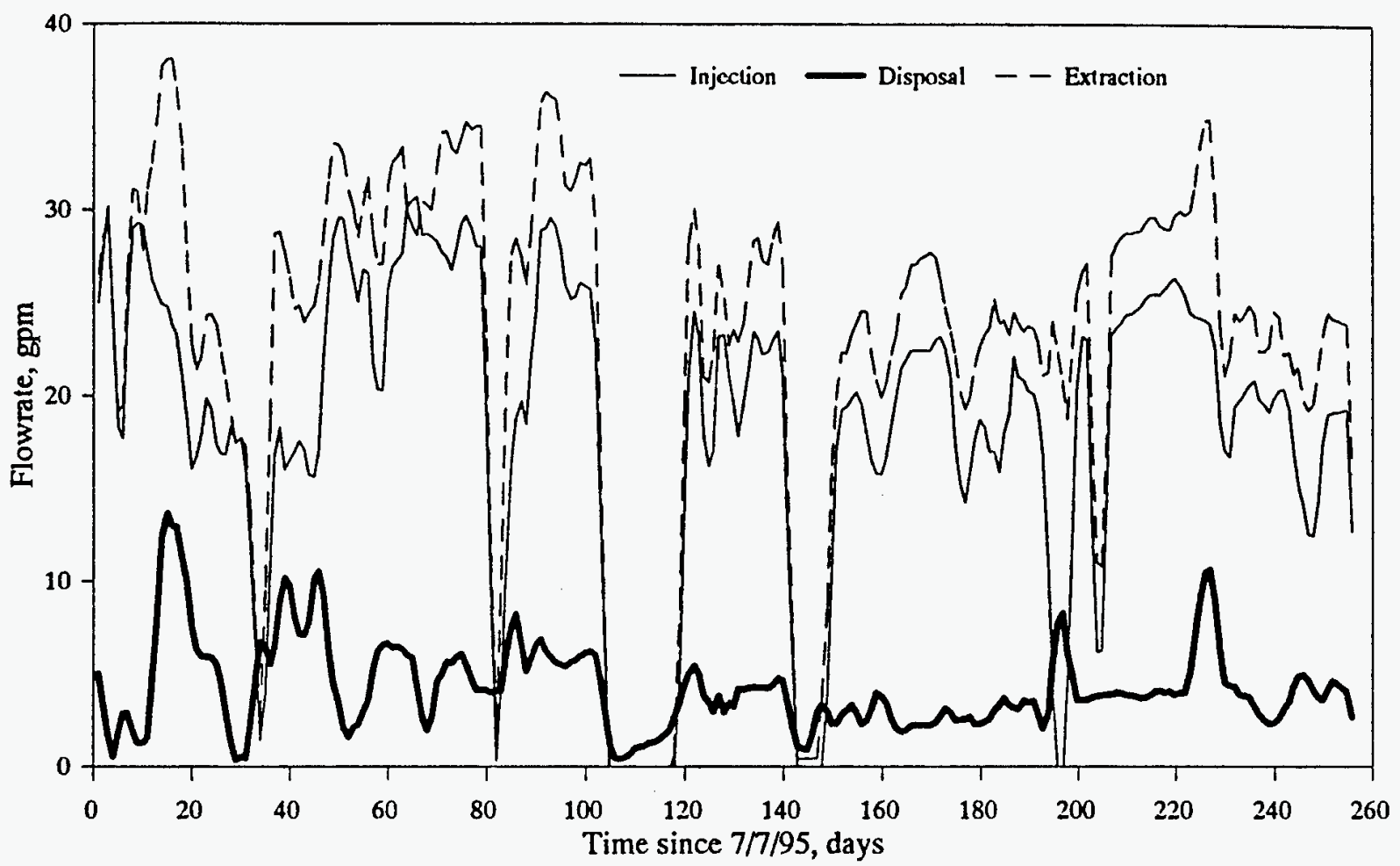

Figure 3. System Flow Rates for the Hot-Water Injection Period, Brodhead Creek CROW Project

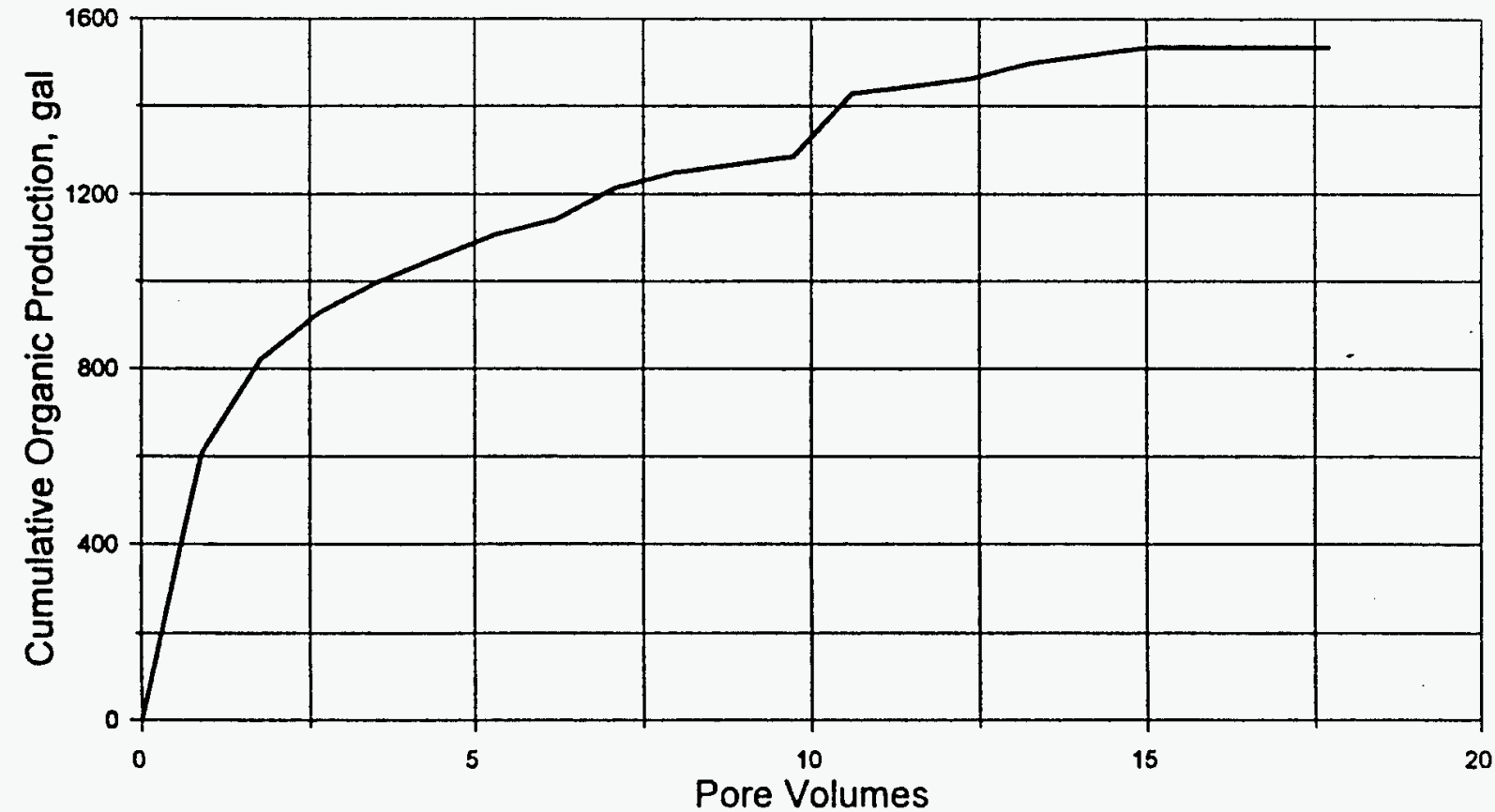

Figure 4. Actual Cumulative Organic Recovery Curve, Brodhead Creek CROW Project 


\section{CONCLUSIONS}

The progress of the project was initially slowed because of problems encountered in the recharacterization of the site, as requested by the EPA, and the length of time required and complexity of the EPA design and approval protocol. The weather and lack of manpower availability caused further delays. The unconsolidated nature of the aquifer and its shallowness have caused problems in obtaining the desired injection rates. These injection problems have resulted in a longer period of operation to attain the desired system throughput.

At the present time, it appears that the EPA remediation criteria for recovery of the organic contaminant (Figure 4) have been met, and the CROW process has been effective at meeting the remediation criteria. However, the temperature criteria have not been met. If further remediation efforts are required at the site to increase the temperature in the process area, then reworking of additional monitor wells into injection wells, replacement or repair of flowmeters, cleaning and refurbishing of the extraction wells and pumps, and retuning of the hot-water heater will be considered. The decision of the EPA as to completion of remediation requirements is expected in April-May 1996. 


\section{DISCLAIMER}

Mention of specific brand names or models of equipment is for information only and does not imply endorsement of any particular brand. 


\section{REFERENCES}

Fahy, L.J., L.A. Johnson Jr., D.V. Sola, S.G. Horn, and J.L. Christofferson, 1992, Bell Pole CROW Pilot Test Results and Evaluation, Proceedings Colorado Hazardous Waste Management Society Annual Conference, 15p.

Gruber, W., 1996, A Fluidized Bed Enhances Biotreatment, Environmental Engineering World, March-April 1996, 27-28.

Johnson, L.A., Jr., and F.D. Guffey, 1990, Contained Recovery of Oily Wastes (CROW) - Final Report. United States Environmental Protection Agency Assistance Agreement CR-815333, RREL, Cincinnati, OH, 45268.

Johnson, L.A., Jr., and A.P. Leuschner, 1992, The CROW Process and Bioremediation for In Situ Treatment of Hazardous Waste Sites, In Hydrocarbon Contaminated Soils and Groundwater, Vol.2, E.J. Calabrese and P.T. Kostecki, eds., Lewis Publishers, Ann Arbor, MI, 343-356. 


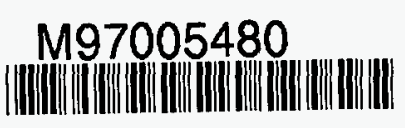

Report Number (14) DOE/MC/30/27-=5783

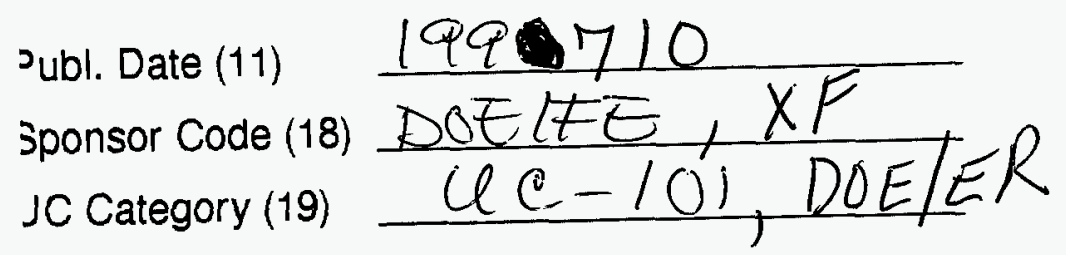

